\title{
Headquarters Involvement, Socialization, and Entrepreneurial Behaviors in Mnc Subsidiaries
}

Decreton, Benoit; Nell, Phillip Christopher; Stea, Diego

\author{
Document Version \\ Accepted author manuscript \\ Published in: \\ Long Range Planning \\ DOI: \\ 10.1016/j.Irp.2018.05.005 \\ Publication date: \\ 2019 \\ License \\ CC BY-NC-ND
}

Citation for published version (APA):

Decreton, B., Nell, P. C., \& Stea, D. (2019). Headquarters Involvement, Socialization, and Entrepreneurial Behaviors in Mnc Subsidiaries. Long Range Planning, 52(4), [101839]. https://doi.org/10.1016/j.Irp.2018.05.005

Link to publication in CBS Research Portal

\section{General rights}

Copyright and moral rights for the publications made accessible in the public portal are retained by the authors and/or other copyright owners and it is a condition of accessing publications that users recognise and abide by the legal requirements associated with these rights.

\section{Take down policy}

If you believe that this document breaches copyright please contact us (research.lib@cbs.dk) providing details, and we will remove access to the work immediately and investigate your claim.

Download date: 26. Apr. 2023

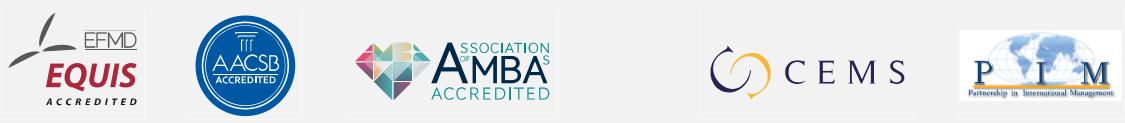




\section{Headquarters Involvement, Socialization, and Entrepreneurial Behaviors in Mnc Subsidiaries}

\section{Benoit Decreton, Phillip Christopher Nell, and Diego Stea}

Journal article (Accepted version)

CITE: Headquarters Involvement, Socialization, and Entrepreneurial Behaviors in Mnc

Subsidiaries. / Decreton, Benoit; Nell, Phillip Christopher; Stea, Diego. In: Long Range Planning, 09.06.2018.

DOl: 10.1016/j.Irp.2018.05.005

Uploaded to Research@CBS: July २०18

(C) 2018. This manuscript version is made available under the CL-BY-NC-ND 4.0 license http://creativecommons.org/licenses/by-nc-nd/4.0/

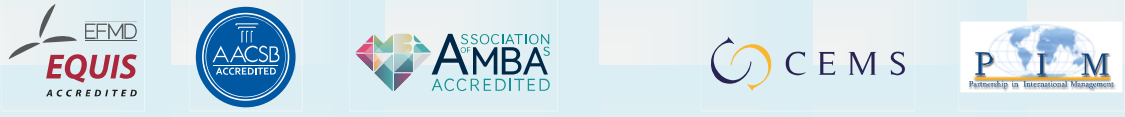




\title{
HEADQUARTERS INVOLVEMENT, SOCIALIZATION, AND ENTREPRENEURIAL BEHAVIORS IN MNC SUBSIDIARIES
}

\author{
Benoit Decreton* \\ WU Vienna University of Business and Economics \\ Welthandelsplatz 1, Building D1, $3^{\text {rd }}$ Floor \\ 1020 Vienna, Austria \\ Email: benoit.decreton@wu.ac.at
}

Phillip C. Nell

WU Vienna University of Business and Economics

\& Copenhagen Business School

Welthandelsplatz 1, Building D1, $3^{\text {rd }}$ Floor

1020 Vienna, Austria

Email: phillip.nell@wu.ac.at

\author{
Diego Stea \\ Copenhagen Business School \\ Kilevej $14,2^{\text {nd }}$ floor \\ 2000 Frederiksberg, Denmark \\ Email: ds.smg@cbs.dk
}

\section{* Corresponding author}

Acknowledgments: We would like to thank, without implicating, Philip Kappen, Marcus Møller Larsen, Sebastian Reiche, and Wolfgang Sofka, as well as participants at the annual meeting of the Academy of International Business in Bangalore in 2015 and at the Strategic Management Society Special conference in St. Gallen in 2015 for insightful comments on earlier versions of this paper. We are also thankful to Tina Ambos and the anonymous reviewers for valuable and constructive comments. 


\title{
HEADQUARTERS INVOLVEMENT, SOCIALIZATION, AND ENTREPRENEURIAL BEHAVIORS IN MNC SUBSIDIARIES
}

\begin{abstract}
Headquarters of multinational corporations can be involved in their subsidiaries and help with the development and transfer of innovative ideas. However, headquarters involvement might not always be desired or needed, and it can thus be perceived as interference with local activities, potentially reducing local willingness to go the extra mile. We address the lack of knowledge about subsidiary manager behavior by answering the following question: How does headquarters involvement influence the proactive behavior of subsidiary managers to push for new and innovative ideas? Using data from 120 top managers in subsidiaries of multinational corporations, we find that the negative relationship between headquarters involvement and their subsidiary managers' support for initiatives can be reduced when socialization mechanisms such as a common corporate culture or rotation programs are put in place.
\end{abstract}

Keywords: Headquarters involvement; subsidiary initiatives; entrepreneurial behaviors; socialization. 


\section{INTRODUCTION}

One important way in which headquarters contribute to the competitiveness of multinational corporations (MNCs) is by orchestrating the emergence and diffusion of innovative ideas across globally dispersed units (Doz, Santos and Williamson, 2001). In this role, headquarters face a fundamental challenge: although headquarters can help with the development and transfer of subsidiary initiatives by being involved locally in their subsidiaries (Ciabuschi, Dellestrand and Martin, 2011), local involvement is not always desired or needed by subsidiary managers and can thus be perceived as undue interference, potentially discouraging subsidiary managers from going the extra mile (Bouquet, Barsoux and Levi, 2015; Conroy and Collings, 2016).

The broader discussion of the involvement of headquarters in subsidiary activities (Mudambi, 2011; Narula, 2014) implicitly highlights an apparently irreconcilable tension between the potentially positive effects of involvement for overall efficiency and coordination, and the potentially negative effects of involvement for local initiative-taking (Foss, Foss and Nell, 2012; Stea, Foss and Foss, 2015). However, little is known about the consequences that headquarters involvement has on the proactive behavior of subsidiary managers. In fact, most of the literature on headquarters involvement and subsidiary initiatives focuses on the organizational level of analysis and neglects subsidiary managers' reactions to headquarters involvement and the motivational and behavioral elements underlying subsidiary initiatives (Ciabuschi, Dellestrand and Martin, 2011; Schmid, Dzedek and Lehrer, 2014; Strutzenberger and Ambos, 2014).

We see the neglect of the individual manager as problematic. Qualitative and conceptual studies indicate that headquarters involvement likely discourage subsidiary managers from acting in proactive ways (Ciabuschi, Forsgren and Martin, 2011; Conroy and Collings, 2016; Foss, Foss and Nell, 2012). However, the proactive behavior of subsidiary managers has recently been shown to significantly influence the emergence of subsidiary initiatives that can be beneficial for the whole MNC (Nuruzzaman, Gaur and Sambharya, 2018; O'Brien et al., 2018). Thus, we want to investigate how headquarters involvement influences the proactive behavior of subsidiary managers to push for new and innovative ideas in their units (what we refer to as 'initiative facilitation behavior'); we also investigate the circumstances under which this effect might be stronger or weaker.

In this paper, we propose that headquarters can negatively influence the initiative facilitation behavior of subsidiary managers but that this relationship depends on the importance of intraorganizational boundaries. Individuals divide the world into the group to which they belong (the in-group) and the other group (the out-group) (Tajfel and Turner, 1979). When the boundaries between the two groups are salient, stereotyping and conflicts are likely to occur (Hinds and Mortensen, 2005; Kramer, 1999). In contrast, cooperation between the different groups is facilitated when the boundaries are not strong and easily crossed by individuals (Schotter et al., 2017; Vora and Kostova, 2007). Accordingly, we argue that socialization mechanisms - that is, mechanisms that facilitate the development of a shared understanding and mission across the organization - reduce the importance of boundaries between the subsidiaries and the other units of the MNC. Information and knowledge about the subsidiaries should flow better to headquarters as a result of socialization, thus increasing mutual understanding, making 
headquarters more aware of when to be involved and how, and helping subsidiary managers better understand the rationale behind headquarters involvement. All of this should lead to headquarters being involved without necessarily compromising subsidiary managers' initiative facilitation behavior.

With this study, we make important contributions to the literatures on headquarters involvement and subsidiary initiatives. Being involved is a way for headquarters to contribute to the development and transfer of subsidiary initiatives. Accordingly, previous studies have found that headquarters involvement can add value to their subsidiaries and to the overall MNC (Ciabuschi, Dellestrand and Martin, 2011; Nell and Ambos, 2013). In contrast, our study shows that headquarters involvement actually hampers a behavior that enables subsidiary initiatives to emerge in the first place. We extend the idea that headquarters involvement, which is perceived as inappropriate by subsidiary managers, is likely to harm entrepreneurial and proactive behaviors (Ciabuschi, Forsgren and Martin, 2011; Foss, Foss and Nell, 2012; Stea, Foss, and Foss, 2015) by identifying socialization mechanisms as boundary conditions of this relationship.

Additionally, consistent with prior research, our study indicates that socialization mechanisms can be used to softly control the actions of subsidiaries (Nohria and Ghoshal, 1994; Björkman, Rasmussen and Li, 2004). However, our study also extends Foss, Foss and Nell's (2012) proposition that socialization influences the extent to which headquarters become involved. Indeed, given that socialization mitigates the negative consequences of headquarters involvement, it seems that socialization influences the appropriateness of headquarters involvement or at least its perceived appropriateness by the subsidiary managers.

Finally, by introducing a new measure that captures the proactive behavior of subsidiary managers to push for and support the emergence of innovative ideas in their units, we elaborate on recent studies that highlight the importance of subsidiary manager activities (O'Brien et al., 2018; Strutzenberger and Ambos, 2014). Headquarters involvement can increase the quality of subsidiary initiatives and their applicability to other parts of the MNC. Our study highlights that it is important to consider subsidiary manager behavior in the subsidiary initiative process because - under certain circumstances - headquarters involvement is negatively related to a key behavioral element behind subsidiary initiatives.

\section{LITERATURE BACKGROUND}

\section{Headquarters involvement and subsidiary initiatives}

The existence of the headquarters unit is justified by its ability to add or create value for the whole firm (Campbell, Goold and Alexander, 1995). Accordingly, headquarters are responsible for organizing the firm's activities in a way that strengthens the competitiveness of the firm (Chandler, 1991). Headquarters can create value by contributing to the development of these initiatives and by organizing synergies with other subsidiaries (Birkinshaw, Ambos and Bouquet, 2017; Collis and Montgomery, 1998; Decreton et al., 2017; Goold and Campbell, 1998). However, through those actions, headquarters interfere with their subsidiary managers' activities 
in ways that can be detrimental to the conditions of subsidiary initiatives (Stea, Foss and Foss, 2015). This dilemma makes it particularly challenging for headquarters to manage the emergence and diffusion of innovative ideas (Mudambi, 2011; Narula, 2014).

Being actively involved in their subsidiaries gives headquarters the opportunity to contribute to the development of local initiatives. Headquarters that are engaged in their subsidiaries have been shown to add value to those subsidiaries by providing them with guidance and advice (Ambos and Schlegelmilch, 2007; Foss, 1997), as well as relevant information, knowledge, and resources (Dellestrand and Kappen, 2012; Nell, Decreton and Ambos, 2016). In addition, headquarters can add value by challenging their subsidiaries' strategies and tactics in developing initiatives (Nell and Ambos, 2013).

Organizing synergies between subsidiaries is another aspect of the parenting advantage that is important for subsidiary initiatives (cf. Campbell, Goold and Alexander, 1995; Chandler, 1991; Egelhoff, 2010; Goold, Campbell and Alexander, 1998). By being involved in their subsidiaries, headquarters can steer local initiatives in particular directions (Forsgren, Holm and Johanson, 2005; Foss, 1997). For example, headquarters managers active in their subsidiaries' boards can help to coordinate the subsidiary's activities and ensure that locally developed initiatives can be useful elsewhere in the firm (Du, Deloof and Jorissen, 2011; 2015; Leksell and Lindgren, 1982). Additionally, when headquarters are involved in their subsidiaries, the legitimacy of the initiatives and projects undertaken in these subsidiaries increases, which facilitates their transfer to other parts of the firm. Thus, headquarters involvement has been found to influence the impact and importance of subsidiary innovation not only at the subsidiary level but also at the MNC level (Ciabuschi, Dellestrand and Martin, 2011).

Some recent work suggests that the positive consequences that headquarters involvement seems to have for the subsidiary or the MNC are not equally straightforward for the willingness of subsidiary managers to go the extra mile. Indeed, managers at headquarters are at a knowledge disadvantage and do not necessarily know the best times to become involved in their subsidiaries (Alfoldi, Clegg and McGaughey, 2012). Consequently, headquarters become involved because of the normative expectations associated with their hierarchical status, leading to potentially inappropriate and harmful involvement (Ciabuschi, Forsgren and Martin, 2012; 2017; Lind and Kang, 2017; Yamin, Tsai and Holm, 2011). In a conceptual study, Foss, Foss and Nell (2012) proposed that headquarters involvement can be perceived as micro-management and can negatively influence the efforts of subsidiary managers both in their job roles and in their extrarole behaviors. Additionally, the knowledge disadvantage of headquarters can lead to unrealistic demands that frustrate subsidiary managers (Holm et al., 2017). Along these lines, headquarters involvement that does not correspond to what headquarters previously promised can trigger subsidiary manager behaviors that are not necessarily aligned with what the headquarters expects (ul Haq, Drogendijk and Holm, 2017). Other qualitative studies have shown that headquarters involvement, even when well-intentioned, can 'suffocate' the subsidiary managers (e.g., with too many information requests or visits) and harm enthusiasm and extra-role behavior (Bouquet, Barsoux and Levy, 2015; Conroy and Collings, 2016). 
The literature on subsidiary initiatives is relatively quiet on the question of how headquarters involvement possibly influences the entrepreneurial behavior of subsidiary managers. In fact, this literature has started to acknowledge a lack of understanding about what stimulates subsidiary managers to act in an entrepreneurial manner (Schmid, Dzedek and Lehrer, 2014; Strutzenberger and Ambos, 2014). Arguably, subsidiary managers play an important role in influencing the activities undertaken in subsidiaries. However, only a few recent studies have empirically explored how the characteristics and activities of subsidiary managers matter in enabling subsidiary initiatives (Dörrenbächer and Gammelgaard, 2016; Nuruzzaman, Gaur and Sambharya, 2018; O’Brien et al., 2018).

Overall, research has shown that being involved can help headquarters to add value to their subsidiaries and to the MNC. While qualitative work supports the idea that headquarters involvement can have negative consequences for the willingness of subsidiary managers to go the extra mile, we know little about the conditions under which this happens. Particularly, we lack knowledge about the influence of headquarters involvement on the proactive entrepreneurial behavior of subsidiary managers. Nevertheless, the literature on boundaries in MNCs provides insights into the relationships between organizational units, and those insights are relevant to this study.

\section{Boundaries in MNCs}

Boundaries between organizational sub-groups can be more or less important, and reducing the thickness of those boundaries and helping individuals to cross them is valuable for overall coordination (Hornsey and Hogg, 2000). This can be done with organizational socialization mechanisms such as establishing a common corporate culture and / or with individual socialization mechanisms such as rotation programs (Smale et al., 2015; Schotter et al., 2017).

Organizational-level socialization mechanisms that facilitate the development of a shared understanding and mission across the organization (Van Maanen and Schein, 1977) (e.g., common corporate culture) have a long history in the literature on headquarters-subsidiary relationships (Kostova, Marano and Tallman, 2016). Nohria and Ghoshal (1994) initially suggested that closely aligned interests and values are an effective way to manage headquarterssubsidiary relations. Building on this perspective, many others have considered the use of socialization as a way to increase trust and communication, thus leading to better informationand knowledge-sharing across MNC units (Björkman, Rasmussen and Li, 2004; Gupta and Govindarajan, 2000; Nahapiet and Ghoshal, 1998; Noorderhaven and Harzing, 2009). More recently, scholars have initiated a discussion on the role of socialization in the dual identification of managers with both their units and the overall MNC (Pant and Ramachandran, 2017; Smale et al., 2015; Vora, Kostova and Roth, 2007). In sum, by increasing shared goals and values across the MNC, organizational socialization mechanisms have been shown to reduce the thickness of boundaries between the different units and to increase overall coordination of the MNC (BarnerRasmussen and Björkman, 2007).

Individual-level socialization mechanisms that make it easier for individuals to directly cross boundaries between different units (e.g., rotation programs) have also received considerable 
attention in the MNC literature (Kostova, Marano and Tallman, 2016; Schotter et al., 2017). Transferring managers across different units of the MNC has been shown to be an important way to generate loose-coupling and interdependence between units (Edström and Galbraith, 1977; Harzing, 1999; 2001). Recently, boundary-spanning mechanisms have been shown to increase knowledge sharing and understanding of what other units of the MNC are doing, thus fostering confidence in other units and a higher willingness to cooperate with them (Klueter and Monteiro, 2017; Schotter and Beamish, 2011). In addition, Kleinbaum and Stuart (2014) found that individuals sent on an assignment at their company's headquarters created relationships with other units of the firm and also maintained these connections after coming back to their units. Overall, mechanisms that prompt individuals to cross organizational boundaries directly are an important way of increasing collaboration between units of the MNC (Mudambi, 2011).

In addition, while most of the literature has conceptualized these mechanisms as means by which headquarters can control their subsidiaries, shared goals and values, as well as greater collaboration and linkages, might also influence headquarters' activities. Foss, Foss and Nell (2012: 255), for example, suggested that headquarters can "get socialized as well" and that this might reduce the opportunistically motivated involvement of headquarters in their subsidiaries.

In sum, research has focused on how headquarters involvement can add value to their subsidiaries and to the MNC. However, recent qualitative and conceptual contributions urge us to pay more attention to the consequences of headquarters involvement for subsidiary manager behavior. According to the literature on boundaries in MNCs, it appears that socialization mechanisms can be an important element of this relationship.

\section{HYPOTHESIS DEVELOPMENT}

By being involved in their subsidiaries, headquarters are better able to add value to them (Nell and Ambos, 2013). Headquarters involved in their subsidiaries can provide appropriate guidance and advice (Ambos and Schlegelmilch, 2007; Foss, 1997) as well as relevant information, knowledge, and resources (Dellestrand and Kappen, 2012; Nell, Decreton and Ambos, 2016). However, we argue that headquarters involvement is likely to have negative consequences for the behavior of subsidiary managers.

In particular, we posit that subsidiary managers can perceive headquarters involvement as a burden that reduces their ability and inclination to facilitate subsidiary initiatives. This burden manifests itself in the preparation for, supervision of, and follow-up to visits from headquarters' managers (Bouquet, Barsoux and Levy, 2015). These tasks are time- and energy-consuming and reduce the attention that subsidiary managers can direct towards identifying and supporting new opportunities in their units.

In addition, the willingness of subsidiary managers to go the extra mile is likely to be reduced when headquarters is involved. Creative entrepreneurial processes such as subsidiary initiatives require a significant amount of enthusiasm from the individuals pursuing them. Indeed, individuals are very unlikely to take the risks inherent to these processes if they are not strongly inclined to make extra efforts in their jobs (Dewett, 2007; Marvel et al., 2007). However, the 
involvement of managers from headquarters in their subsidiaries' activities is a form of interference that reminds the subsidiary managers that headquarters' managers have the final word, even though subsidiary managers are given some discretion over the activities they pursue locally (Baker, Gibbons and Murphy, 1999; Foss, 2003; Foss, Foss and Vazquez, 2006). As a result of the interference associated with the involvement of headquarters' managers, subsidiary managers will be less eager to make extra efforts in and beyond their jobs (Stea, Foss and Foss 2015). Eventually, reduced willingness to go the extra mile will lead to less proactivity in facilitating the development of new ideas (Crant, 2000; Grant and Ashford, 2008).

Overall, we argue that headquarters involvement will reduce the ability and willingness of subsidiary managers to facilitate the development of entrepreneurial activities and will make the subsidiary environment less favorable to creativity and innovativeness.

Hypothesis 1: Headquarters involvement will be negatively related to the initiative facilitation behavior of subsidiary managers.

Organizational socialization mechanisms were initially presented as a way to integrate new employees by teaching them the goals, values, and beliefs of the organization (Chao et al., 1994; Van Maanen and Schein, 1979). Yet, organizational socialization mechanisms are also relevant for the management of multi-unit firms (Gupta and Govindarajan, 2000; Nohria and Ghoshal, 1994). Mechanisms such as international task groups and a common corporate culture reduce the salience of boundaries between the different organizational units. This increases trust in and identification with members of other units of the MNC (Reade, 2001; Smale et al., 2015; Vora and Kostova, 2007).

Organizational socialization mechanisms provide occasions for more formal and informal knowledge exchanges (Schulz, 2003). Subsidiary managers have more opportunities to share their concerns and wishes with headquarters' managers (Foss, Foss and Nell, 2012), leading to stronger alignment among the different units (Nohria and Ghoshal, 1994). Given the resulting shared understanding of what other units are doing, headquarters involvement will be more informed (Ciabuschi, Forsgren and Martin, 2011; Foss, Foss and Nell, 2012).

Subsidiary managers' reactions to headquarters involvement will be more positive if organizational socialization mechanisms are in place. Indeed, reduced organizational boundaries will make subsidiary managers less suspicious about headquarters' actions (Hornsey and Hogg, 2000; Kramer, 1999) and will increase subsidiary-parent cooperation (Lee and Williams, 2007; Vora and Kostova, 2007). In turn, headquarters involvement should be less likely to be perceived as a controlling exercise and more likely to be seen as a positive and non-threatening action. For this reason, it should also be less likely to negatively affect subsidiary managers' willingness to push for and support local initiatives (Ghoshal and Bartlett, 1988; Reade, 2003).

In sum, organizational socialization should act as a buffer (Andersson, Cuervo-Cazurra and Nielsen, 2014) and reduce the negative effects of headquarters involvement on their subsidiary managers' engagement and support for initiatives. 
Hypothesis 2: Organizational socialization mechanisms will positively moderate the negative relationship between headquarters involvement and the initiative facilitation behavior of subsidiary managers.

Individual socialization mechanisms such as inpatriation and expatriation programs help and encourage individuals to cross intra-organizational boundaries, however salient they may be (Edstrom and Galbraith, 1977; Harzing, 1999; 2001). These intra-company transfers of individual managers enable the enactment of international networks of practice by helping to develop strong and lasting relationships across organizational units (Kleinbaum and Stuart, 2014).

These relationships are key to increasing the shared understanding between headquarters and subsidiaries. Indeed, subsidiary managers with experience in their companies' headquarters are well positioned to improve the scope and richness of knowledge transfer through formal and informal channels (Gupta and Govindarajan, 2000; Cano-Kollmann et al., 2016). Thus, subsidiary managers who have developed strong relationships with managers at the firm's headquarters can be efficient conduits of information and knowledge (Birkinshaw, Ambos and Bouquet, 2017; Tippmann, Scott and Parker, 2017). Thus, they are better able to convey their wishes and to express when the involvement of headquarters' managers is needed and desired.

Additionally, subsidiary managers with work experience at their companies' headquarters have a greater comprehension of organizational dynamics within the MNC network (Nuruzzaman, Gaur and Sambharya, 2018). They can also use their personal connections to obtain knowledge about strategic and operational matters (Gaur, Delios and Singh, 2007). As a result, work experience at headquarters is likely to increase the subsidiary managers' understanding of why headquarters' managers become involved.

A logic of good faith should be more prevalent among subsidiary managers who have had the opportunity for direct contact with headquarters (Schotter et al., 2017). In fact, a stronger willingness to cooperate and collaborate between the subsidiary's and the headquarters' managers should follow. Following work experience at their companies' headquarters, subsidiary managers should be more likely to overcome home-country bias and to develop a global mindset (Perlmutter, 1969; Prahalad and Bettis, 1986) that will lead to better interaction with headquarters managers (Black, Gregersen and Mendenhall, 1992; Mudambi, 2011). As a result, subsidiary managers should perceive headquarters involvement more positively and be more inclined to promote and support the development of new ideas.

Taken together, these arguments suggest that individual-level socialization mechanisms that allow the transfer of managers from subsidiaries to headquarters should reduce the negative effects of headquarters involvement on subsidiary managers' engagement and support for initiatives.

Hypothesis 3: Individual socialization mechanisms will positively moderate the negative relationship between headquarters involvement and the initiative facilitation behavior of subsidiary managers. 


\section{METHODS}

\section{Sample and procedure}

To compile our sample, we used the Orbis database to randomly select 2000 manufacturing subsidiaries located in six European countries. Data collection was conducted between November 2013 and August 2015. We did not restrict the home countries of the MNC, which allowed for collocation between headquarters and subsidiaries (for 9\% of our final sample). To ensure a link between the subsidiary and the headquarters, the minimum level of ownership was set to at least $50.01 \%$, and to avoid private equity firms, hedge funds or families, we selected only industrial companies as domestic or global ultimate owners. For each subsidiary, we used the Orbis database and online research to check whether there was a real parent-subsidiary relationship and not a single individual or a financial institution as the main shareholder. We identified the direct email addresses of the general managers of these companies through Orbis and online research. Eventually, we contacted 1576 subsidiary managers.

The questionnaire was developed by incorporating feedback from two academics who identified questions that were vague, ambiguous, or the source of a possible bias. The questionnaire was created in English and then translated into the different local languages.

We kept track of respondents and non-respondents and insured confidentiality by using serial numbers on the survey. One follow-up round by mail and another by email, combined with a promise to provide results (Dillman, 2000) aimed to ensure a higher response rate. The exclusion of responses with missing values led to a final sample size of 120 subsidiaries in $116 \mathrm{MNCs}$. The subsidiaries were located in Austria (34\%), Germany (23\%), Denmark (16\%), Norway (13\%), Portugal (8\%), and Spain (6\%). The locations of the headquarters were distributed globally, with $28 \%$ in Germany, 13\% in Austria, 11\% in Norway, $8 \%$ in Switzerland, 7\% in Denmark, 6\% in the USA, 5\% in Sweden, 5\% in France, and the remaining 20\% in 13 other countries. Across the six countries, we achieved a response rate of $7.6 \%$. While this is not ideal, it is within the scope of recent multi-country studies (Harzing, 1999). To check for non-response bias, we examined whether respondents and non-respondents differed on several aspects. Because we did not find any significant differences in terms of subsidiary age, size, turnover, headquarters turnover or size, we are confident that non-response bias is not an issue.

\section{Measures}

\section{Subsidiary manager initiative facilitation behavior ${ }^{1}$}

\footnotetext{
${ }^{1}$ Following a reviewer's suggestion, we collected additional data for $13 \%$ of the subsidiaries in our sample on the subsidiary initiatives that occurred after the measurement of our dependent variable and found a positive correlation between the two variables $(r=0.4)$, suggesting a positive relationship between our individual-level dependent variable and this subsidiary-level outcome variable.
} 
We aimed to measure a proactive behavior that generates a supportive context for subsidiary initiatives, and we therefore combined concepts from organizational behavior and international business. In particular, we adapted the extra-role behavior scale (used to measure taking charge) developed by Morrison and Phelps (1999: 403) ("a discretionary behavior intended to effect organizationally functional change") to the subsidiary initiative context (Ambos et al., 2010). Subsidiary manager initiative facilitation behavior was captured with a four-item question. Respondents had to rate the different items on a seven-point scale (1: never to 7: all the time). The question was "How often do you personally...that support entrepreneurship activities in your subsidiary?," and the items were "generate creative ideas", "promote and champion ideas", "try to improve procedures", and "try to instill new work methods". Examples of entrepreneurship activities were given in the questionnaire (e.g., new products that were subsequently sold internationally, enhancements to product lines that were already sold internationally) ( $\alpha=0.9)$. We conducted a factor analysis and, as all four items loaded on one factor, we used the extracted factor score in our analysis.

\section{Headquarters involvement}

We collected both primary and secondary data to capture our main independent variable. We used a procedure adapted from Ambos and Schlegelmilch (2007) and first asked the respondents to identify from one to three partners with whom they interact the most (e.g., competitors, suppliers, customers, other firms, universities, local governments, or other institutions). In the next step, respondents had to rate the extent to which their headquarters maintained linkages to each of these local partners on a five-point scale (1: The headquarters does not know this counterpart and 5: there is very frequent contact (more often than once a month)). Additionally, the respondents also had to answer on a seven-point scale (1: strongly disagree and 7: strongly agree) whether managers from the headquarters are very often present when the subsidiary has negotiations with this partner and whether headquarters managers usually want to meet this partner when managers from the headquarters are visiting the subsidiary. We put the three scores on the same scale (1: very low headquarters involvement to 7: very high headquarters involvement) and averaged these for each of the partners, thus creating scores for involvement with partner $1(\alpha=0.9)$, with partner $2(\alpha=0.9)$, and with partner $3(\alpha=0.9)$.

Secondary data were gathered via the Orbis database. We followed Leksell and Lindgren (1982) in assessing the degree of headquarters involvement in their subsidiaries' management and operations by collecting the names of all subsidiary board members and identifying which ones were headquarters managers. The share of headquarters managers present on the board was then converted to a seven-point scale. This score and the other measures of involvement loaded on one factor $(\alpha=0.8)$, and we used the extracted factor score to capture headquarters involvement in the subsidiary's activities.

\section{Organizational socialization}

To measure organizational socialization, we followed the measure of Nell and Ambos (2013). We asked the subsidiary managers to rate the extent to which they agree with three different statements. The questions concerned the extent to which 1) the subsidiary and the headquarters 
share the same values, 2) there are many joint task forces between subsidiary managers and headquarters executives, and 3) headquarters invests considerable effort in establishing a common corporate culture. We used a seven-point scale (1: strongly disagree and 7: strongly agree). The three scores loaded on one factor $(\alpha=0.6)$, and we used the extracted factor score in our analysis.

\section{Individual socialization}

To measure the individual socialization mechanisms in place (Schotter et al., 2017), we measured each respondent's employment in the headquarters of their current company. Subsidiary managers with work experience outside of their units, and in particular in their company's headquarters, have already crossed intra-organizational boundaries; they are consequently more aware of activities undertaken in other units of the organization and better able to link different units (see Kleinbaum and Stuart, 2014). Our individual socialization variable takes the value of 1 if the subsidiary managers have work experience in their company's headquarters, and 0 otherwise.

\section{Control variables}

We controlled for several variables that had the potential to influence the results of our study. We controlled for subsidiary manager age (logarithmic scale) and education (Master or PhD: 1; other: $0)^{2}$. To differentiate between subsidiaries that have received an entrepreneurial mandate from the headquarters versus those that did not, we asked subsidiary managers the following question: "Your subsidiary has been given by the headquarters the explicit task of being entrepreneurial." The entrepreneurial mandate control variable was integrated as a dummy variable. We controlled for the level of past subsidiary initiatives, as it could influence the level of initiative-taking behavior of subsidiary managers. We used a five-item scale adapted from Ambos et al. (2010). The respondents answered the following question: "To what extent have the following activities occurred over the last 5 years?" on a seven-point scale (1: never to 7: plentifully). The questions referred to new products developed that were then sold internationally, to successful bids for corporate investments in the subsidiary, to new international business activities first developed in the subsidiary, to enhancements to product lines already sold internationally, and to new corporate investments in R\&D or manufacturing attracted by the subsidiary $(\alpha=0.8)$. We also controlled for subsidiary-level variables - such as age and number of employees - using secondary data extracted from Orbis. We controlled for headquarters type by asking subsidiary managers to indicate whether the headquarters they mainly report to is a corporate headquarters (versus divisional or regional) (Yes: 1; No: 0). Finally, we controlled for geographic distance by measuring the distance in kilometers between the subsidiary city and the headquarters city, as indicated by the subsidiary managers. Descriptive statistics and correlations are available in Table 1 .

${ }^{2}$ We did not control for gender as only one subsidiary manager in our sample was a female. 


\section{INSERT TABLE 1 ABOUT HERE}

\section{Common method variance}

We followed different procedures to reduce the likelihood of potential common method bias. First, several of our variables were composed of secondary and/ or objective information. Our independent variable consisted of both primary information from the subsidiary managers and secondary information on the subsidiary board. The dummy capturing the respondent's prior experience at headquarters is very much in line with what $\mathrm{Ng}$ and Feldman call "'objective' background and work history" variables (Ng and Feldman, 2012: 1039), where respondents are asked about precise aspects of their work (e.g., whether they have previously worked at headquarters or not); this information should thus be unlikely to be under/over-reported. Regarding our measure of subsidiary manager initiative facilitation, although individuals may have biased perceptions and biased views of their actual behavior, self-reported measures remain an accepted way of capturing perceptions and behaviors among employees (Howard, 1994). In particular, it may be argued that employees are optimally suited to self-report variables such as the proactive generation of creative behaviors, as they are the ones who are aware of the subtle things they do in their jobs (Janssen, 2004; Shalley, Zhou and Oldham, 2004). Furthermore, although self-reported measures are subject to bias, they have also been found to correlate substantially with supervisory ratings (Axtell et al., 2000).

Second, we ensured anonymity and initiated the questionnaire by stating that some headquarters are involved and others not, that some headquarters require their subsidiary managers to be proactive and some not, thereby indicating that all answers are fine. Additionally, our questionnaire consisted of different scales, and some of them were reversed, which diminishes the risk of biases.

Third, we test a complex model with interaction effects, and this makes it less likely that the respondents are "guided by a cognitive map that includes difficult to visualize interaction and non-linear effects" (Chang, Van Witteloostuijn and Eden, 2010: 179).

In addition, we performed a number of statistical analyses to assess common method bias. First, a Harman's one-factor test on the items indicated that common method bias was not a major issue. That is, multiple factors were detected, and the variance did not merely stem from the first factors (Podsakoff and Organ, 1986). Second, we ran a confirmatory factor analysis including all the underlying items that together form the variables in our model - to test whether they loaded on the same factor (a Single Factor Model). The assumption was that the appearance of a single factor as the common denominator across all items would reflect the presence of common method bias (Podsakoff, MacKenzie, Lee and Podsakoff, 2003). However, in our case, the goodness-of-fit statistics of this model were highly unsatisfactory, suggesting that our data do not suffer from major common methods bias. Finally, we introduced a marker variable to further test for common method bias and gained support for the conclusion that common method testing did not bias our results (Malhotra, Kim and Patil, 2006). 
Taken together, these statistical tests and variable-specific theoretical considerations make us confident that the effects that we capture in our model are not substantially influenced by common method variance.

\section{RESULTS}

We used hierarchical ordinary least squares (OLS) regression analysis to estimate the coefficients and model fit. We checked for the assumptions of linearity, normality of residuals, and undue outliers, but we did not detect any irregularities. We used Cameron \& Trivedi's decomposition of the IM-test to check for heteroskedasticity, and the results were all insignificant. Variance inflation factors were below 10 in all specifications (mean VIF $=1.13$ ), the eigenvalue was high enough (0.51) and the condition number was low enough (24.93) to suggest that multicollinearity was not an issue.

Model 1 includes only the control variables. Model 2 includes the direct effects of organizational and individual socialization. Model 3 includes the direct effect of headquarters involvement. Models 4 and 5 include the moderating effects of organizational and individual socialization, respectively. Finally, Model 6 includes all variables and moderation effects (see Table 2).

\section{INSERT TABLE 2 ABOUT HERE}

Our results support our three hypotheses. As expected in our hypothesis 1 , we found a negative and significant relationship between headquarters involvement and the initiative facilitation behavior of subsidiary managers $(\beta=-0.357 ; p=0.022)$. We found support for our hypothesis 2 on the moderating effect of organizational socialization on the relationship between headquarters involvement and subsidiary manager initiative facilitation behavior $(\beta=0.181 ; \mathrm{p}=$ 0.043). Our hypothesis 3 was also supported, as we found a positive and significant moderating effect individual socialization on the relationships between headquarters involvement and subsidiary manager initiative facilitation behavior $(\beta=0.356 ; p=0.041)$.

Levene's robust test for the equality of variances between the groups was significant for organizational socialization and suggested that the variance in initiative facilitation behavior is restricted at high levels of organizational socialization (Cortina, Köhler and Nielsen, 2015). Levene's robust test was, however, not significant for individual socialization.

\section{INSERT FIGURE 2 ABOUT HERE}

Figure 2 illustrates that the effect of headquarters involvement on subsidiary manager initiative facilitation is strongly negative when subsidiary managers reported low levels of 
organizational socialization $(\beta=-0.557$; $\mathrm{p}<0.001)$ and that this relationship is less negative but insignificant when the subsidiary managers reported high levels of organizational socialization $(\beta$ $=-0.177$; n.s.). In other words, we find support for our buffering interaction hypothesis that headquarters involvement has little influence on initiative facilitation behavior for subsidiary managers with high levels of organizational socialization.

\section{INSERT FIGURE 3 ABOUT HERE}

Similarly, Figure 3 shows that the effect of headquarters involvement on subsidiary manager initiative facilitation is strongly negative when individual socialization mechanisms were not in place $(\beta=-0.358 ; p<0.001)$ and that this relationship is positive but insignificant in the presence of individual socialization mechanisms ( $\beta=-0.002 ; n$.s.). In other words, we find support for our buffering interaction hypothesis that headquarters involvement has little influence on initiative facilitation behavior when individual socialization mechanisms are put in place.

Additional probing of the data revealed that headquarters involvement was negatively and significantly related to initiative facilitation behavior for the managers without individual socialization mechanisms who scored below 5.3 on our 7-point organizational socialization mechanisms measure (29\% of our final sample).

In sum, to counter-balance the negative influence of headquarters involvement on the initiative facilitation behavior of subsidiary managers, individual socialization mechanisms are per se sufficient. However, organizational socialization has to be very high when individual mechanisms are not in place.

We conducted robustness checks to ensure that our model was robust under different specifications (available upon request). First, we kept only our significant control variables and used a restricted sample by including only the subsidiaries that received an explicit entrepreneurial mandate from their headquarters. Second, we ran our model with robust standard errors adjusted for subsidiary country clusters, for headquarters country clusters, and for subsidiary NACE (4 digits) clusters. Third, we ran the model using alternative control variables (e.g. number of years in a leadership position instead of age). Our results hold in these specifications and we are confident about the stability of our model.

\section{DISCUSSION}

We opened this paper by highlighting the dilemma that headquarters face when trying to manage subsidiary initiatives. Headquarters need to be involved to support the development and transfer of subsidiary initiatives. However, being involved interferes with the subsidiary managers' activities and can harm their willingness to push for such initiatives. Our aim with this study was to show how MNCs can reconcile the inherent tension around the effects of headquarters 
involvement in their subsidiary activities. We did so by studying the influence of mechanisms that can reduce the negative relationship between headquarters involvement and subsidiary manager initiative facilitation behavior. Our results show that headquarters that set up mechanisms that reduce the salience of boundaries between MNC units or that encourage individuals to cross those boundaries are at a lower risk of negatively influencing the proactive behavior of their subsidiary managers when managers from the headquarters cross these boundaries themselves and become involved in their subsidiaries.

This paper makes important contributions to research on headquarters involvement and subsidiary initiatives. A few recent studies have suggested that we know little about the consequences of headquarters involvement for subsidiary manager behavior (Bouquet, Barsoux and Levi, 2015; Ciabuschi, Forsgren and Martin, 2011). Our study builds on that suggestion in investigating a behavior that facilitates the emergence and development of new ideas in subsidiaries: subsidiary manager initiative facilitation behavior. In this way, we are able to show that while headquarters might get involved to provide guidance and support for the development and transfer of innovative ideas (Ambos and Schlegelmilch, 2007; Ciabuschi, Dellestrand and Martin, 2011; Nell and Ambos, 2013), headquarters involvement in their subsidiaries harms a behavior that enables these ideas to emerge in the first place. We go one step further in identifying socialization mechanisms as boundary conditions for this dilemma. The firms in our study that had organizational and / or individual socialization mechanisms in place were less likely to see headquarters involvement as negatively influencing the initiative facilitation behavior of their subsidiary managers. In other words, these socialization mechanisms appear to be a way in which firms can reconcile the tension around the effects of headquarters involvement in their subsidiary activities. Additionally, while socialization mechanisms have mostly been conceptualized as ways to softly control the (re)actions of international subsidiaries (e.g., Nohria and Ghoshal, 1994; Björkman, Rasmussen and Li, 2004), we extend their applicability. Consistent with prior literature, our results suggest that socialization mechanisms can indeed control subsidiary managers' reactions to headquarters' actions in that subsidiary managers understand the rationale of headquarters involvement better and react more positively. Yet, our study also indicates that socialization mechanisms can limit inappropriate and undesired headquarters' actions in that headquarters become more knowledgeable about when to be involved. In other words, socialization mechanisms enhance mutual interdependence between headquarters and subsidiaries so that opportunism from both sides is restrained. Thus, we build on the conceptual model by Foss, Foss and Nell (2012) regarding the use of socialization mechanisms to better manage headquarters involvement and the coordination of the MNC. While they suggested that socialization influences the extent to which headquarters get involved in their subsidiaries as well as how this involvement relates to MNC performance, our results suggest that it can also influence how headquarters involvement is perceived in the subsidiaries.

In addition, our dependent variable extends research on subsidiary initiatives. Although subsidiary managers have the responsibility to support the realization of initiatives, little research has been done on what influences the extent to which they actually do so (O'Brien et al., 2018). Two literature reviews have noted that the individual actor has been neglected and have 
suggested parallels with organizational behavior and the notion of proactive behavior (Schmid, Dzedek and Lehrer, 2014; Strutzenberger and Ambos, 2014). With this paper, we are directly addressing this issue in providing a measure that links proactive behavior (Morrison and Phelps, 1999) with subsidiary initiatives (Ambos et al., 2010). More specifically, we increase our understanding of subsidiary manager behavior in showing that a key driver of subsidiary initiatives (i.e., subsidiary manager initiative facilitation behavior) can be negatively related to an important element that actually helps subsidiary initiatives to be useful in other parts of the firms (i.e., headquarters involvement). Along the lines of recent studies (O'Brien et al., 2018; Nuruzzaman, Gaur and Sambharya, 2018), this result stresses the importance of considering the behavior of subsidiary managers when studying subsidiary initiatives.

On a more general level, our study extends our understanding of headquarters-subsidiary relationships (Mudambi, 2011; Narula, 2014; Foss, Foss and Nell, 2012). Our results show that managing the tension between the potentially positive effects of headquarters involvement on overall efficiency and coordination and the potentially negative effects of headquarters involvement on local proactive behaviors is very delicate. We contribute to this literature by highlighting ways to better manage relationships between headquarters and subsidiaries.

\section{Managerial relevance}

Our study provides implications for headquarters and subsidiary managers. Headquarters managers become involved with the aim of creating value for the whole firm. Our results show that, paradoxically, this involvement can be rather negative. Thus, headquarters managers need to be careful when intervening or becoming involved in their subsidiaries. Putting mechanisms in place that establish shared values, goals and a common corporate culture, as well as staffing subsidiary managers at headquarters, can - for example - be ways for headquarters managers to reduce the negative consequences of their involvement on proactive behaviors in their subsidiaries. In addition, it appears important for subsidiary managers to make use of the different socialization opportunities that are available to them in order to mitigate headquarters involvement as well as increase their understanding of why headquarters has become involved.

\section{Limitations and future research}

Our study comes with some limitations that offer exciting avenues for future research. First, while we aimed to investigate the individual behavior of proactively pushing for initiatives, we have not measured the motivation of subsidiary managers directly. Instead, we used motivation as an abstract intervening concept that guided our argumentation (see also Ambos and Schlegelmilch, 2007 and Egelhoff, 1982). Future studies could integrate more individual-level variables such as proactive personality, need for achievement, and motivation to provide a broader comprehension of what drives subsidiary managers to work towards global efforts. Second, the cross-sectional nature of our results makes it difficult to establish unidirectional relations between our constructs, despite the fact that our independent variable consists of activities that take time to develop and that likely took place prior to the behavior captured by the dependent variable. Future research could investigate headquarters involvement prior to the 
behavior of subsidiary managers, as well as consequences at the subsidiary-level. Additionally, given the dynamic relationship between headquarters and subsidiaries, it would be interesting to see how subsidiary initiatives and headquarters involvement evolve over time within the same dyads. We have measured individual socialization mechanisms using a dummy variable, and future research could provide interesting and more detailed insights by using fine-grained measures of this concept. Finally, there are exciting research avenues regarding the role that fairness perceptions and social comparison play in subsidiary managers' reactions to headquarters involvement.

\section{REFERENCES}

Alfoldi, E. A., Clegg, L. J., \& McGaughey, S. L. (2012). Coordination at the edge of the empire: The delegation of headquarters functions through regional management mandates. Journal of International Management, 18(3), 276-292.

Ambos, B., \& Schlegelmilch, B. B. (2007). Innovation and control in the multinational firm: A comparison of political and contingency approaches. Strategic Management Journal, 28(5), 473-486.

Ambos, T. C., Andersson, U., \& Birkinshaw, J. (2010). What are the consequences of initiative-taking in multinational subsidiaries?. Journal of International Business Studies, 41(7), 1099-1118.

Andersson, U., Cuervo-Cazurra, A., \& Nielsen, B. B. (2014). From the editors: Explaining interaction effects within and across levels of analysis. Journal of International Business Studies, 45(9), 1063-1071.

Axtell, C. M., Holman, D. J., Unsworth, K. L., Wall, T. D., Waterson, P. E., \& Harrington, E. (2000). Shopfloor innovation: Facilitating the suggestion and implementation of ideas. Journal of Occupational and Organizational Psychology, 73(3), 265-285.

Baker, G., Gibbons, R., \& Murphy, K. J. (1999). Informal authority in organizations. Journal of Law, Economics, and organization, 15(1), 56-73.

Barner-Rasmussen, W., \& Björkman, I. (2007). Language fluency, socialization and inter-unit relationships in Chinese and Finnish subsidiaries. Management and Organization Review, 3(1), 105-128.

Birkinshaw, J., Ambos, T. C., \& Bouquet, C. (2017). Boundary spanning activities of corporate HQ executives insights from a longitudinal study. Journal of Management Studies, 54(4), 422-454.

Björkman, I., Barner-Rasmussen, W., \& Li, L. (2004). Managing knowledge transfer in MNCs: The impact of headquarters control mechanisms. Journal of International Business Studies, 35(5), 443-455.

Black, J. S., Gregersen, H. B., \& Mendenhall, M. E. (1992). Toward a theoretical framework of repatriation adjustment. Journal of International Business Studies, 23(4), 737-760.

Bouquet, C., Barsoux, J. L., \& Levy, O. (2015). The perils of attention from headquarters. MIT Sloan Management Review, 56(2), 16-18.

Campbell, A., Goold, M., \& Alexander, M. (1995). Corporate strategy: The quest for parenting advantage. Harvard Business Review, 73(2), 120-132.

Cano-Kollmann, M., Cantwell, J., Hannigan, T. J., Mudambi, R., \& Song, J. (2016). Knowledge connectivity: An agenda for innovation research in international business. Journal of International Business Studies, 47(3), 255262.

Chandler, A. D. (1991). The functions of the HQ unit in the multibusiness firm. Strategic Management Journal, 12(S2), 31-50.

Chang, S. J., Van Witteloostuijn, A., \& Eden, L. (2010). From the editors: Common method variance in international business research. Journal of International Business Studies, 41(2), 178-184.

Chao, G. T., O'Leary-Kelly, A. M., Wolf, S., Klein, H. J., \& Gardner, P. D. (1994). Organizational socialization: Its content and consequences. Journal of Applied psychology, 79(5), 730. 
Ciabuschi, F., Dellestrand, H., \& Martín, O. M. (2011). Internal embeddedness, headquarters involvement, and innovation importance in multinational enterprises. Journal of Management Studies, 48(7), 1612-1639.

Ciabuschi, F., Forsgren, M., \& Martín, O. M. (2011). Rationality vs ignorance: The role of MNE headquarters in subsidiaries' innovation processes. Journal of International Business Studies, 42(7), 958-970.

Ciabuschi, F., Forsgren, M., \& Martin, O. M. (2012). Headquarters involvement and efficiency of innovation development and transfer in multinationals: A matter of sheer ignorance?. International Business Review, 21(2), 130-144.

Ciabuschi, F., Forsgren, M., \& Martín, O. M. (2017). Value creation at the subsidiary level: Testing the MNC headquarters parenting advantage logic. Long Range Planning, 50(1), 48-62.

Collis, D. J., \& Montgomery, C. A. (1998). Corporate strategy: A resource-based approach. Boston, MA: Irwin/McGraw-Hill.

Conroy, K. M., \& Collings, D. G. (2016). The legitimacy of subsidiary issue selling: Balancing positive \& negative attention from corporate headquarters. Journal of World Business, 51(4), 612-627.

Cortina, J. M., Köhler, T., \& Nielsen, B. B. (2015). Restriction of variance interaction effects and their importance for international business research. Journal of International Business Studies, 46(8), 879-885.

Crant, J. M. (2000). Proactive behavior in organizations. Journal of Management, 26(3), 435-462.

Decreton, B., Dellestrand, H., Kappen, P., \& Nell, P. C. (2017). Beyond Simple Configurations: The Dual Involvement of Divisional and Corporate Headquarters in Subsidiary Innovation Activities in Multibusiness Firms. Management International Review, 57(6), 855-878.

Dellestrand, H., \& Kappen, P. (2012). The effects of spatial and contextual factors on headquarters resource allocation to MNE subsidiaries. Journal of International Business Studies, 43(3), 219-243.

Dewett, T. (2007). Linking intrinsic motivation, risk taking, and employee creativity in an R\&D environment. $R \& D$ Management, 37(3), 197-208.

Dillman, D. A. (2000). Mail and internet surveys: The tailored design method (Vol. 2). New York: Wiley.

Dörrenbächer, C., \& Gammelgaard, J. (2016). Subsidiary initiative taking in multinational corporations: the relationship between power and issue selling. Organization Studies, 37(9), 1249-1270.

Doz, Y. L., Santos, J., \& Williamson, P. J. (2001). From global to metanational: How companies win in the knowledge economy. Harvard Business Press.

Du, Y., Deloof, M., \& Jorissen, A. (2011). Active boards of directors in foreign subsidiaries. Corporate Governance: An International Review, 19(2), 153-168.

Du, Y., Deloof, M., \& Jorissen, A. (2015). The roles of subsidiary boards in multinational enterprises. Journal of International Management, 21(3), 169-181.

Edström, A., \& Galbraith, J. R. (1977). Transfer of managers as a coordination and control strategy in multinational organizations. Administrative Science Quarterly, 22(2), 248-263.

Egelhoff, W. G. (1982). Strategy and structure in multinational corporations: An information-processing approach. Administrative Science Quarterly, 27(3), 435-458.

Egelhoff, W. G. (2010). How the parent headquarters adds value to an MNC. Management International Review, 50(4), 413-431.

Forsgren, M., Holm, U., \& Johanson, J.(2005). Managing the embedded multinational. Cheltenham: Edward Elgar Publishing

Foss, K., Foss, N. J., \& Nell, P. C. (2012). MNC organizational form and subsidiary motivation problems: Controlling intervention hazards in the network MNC. Journal of International Management, 18(3), 247-259.

Foss, K., Foss, N. J., \& Vázquez, X. H. (2006). 'Tying the manager's hands': constraining opportunistic managerial intervention. Cambridge Journal of Economics, 30(5), 797-818.

Foss, N. J. (1997). On the rationales of corporate headquarters. Industrial and Corporate Change, 6(2), 313-338.

Foss, N. J. (2003). Selective intervention and internal hybrids: Interpreting and learning from the rise and decline of the Oticon spaghetti organization. Organization Science, 14(3), 331-349.

Gaur, A. S., Delios, A., \& Singh, K. (2007). Institutional environments, staffing strategies, and subsidiary performance. Journal of Management, 33(4), 611-636. 
Ghoshal, S., \& Bartlett, C. A. (1988). Creation, adoption, and diffusion of innovations by subsidiaries of multinational corporations. Journal of International Business Studies, 19(3), 365-388.

Goold, M., \& Campbell, A. (1998). Desperately seeking synergy. Harvard Business Review, 76(5), 131-143.

Goold, M., Campbell, A., \& Alexander, M. (1998). Corporate strategy and parenting theory. Long Range Planning, 31(2), 308-314.

Grant, A. M., \& Ashford, S. J. (2008). The dynamics of proactivity at work. Research in Organizational Behavior, 28, 3-34.

Gupta, A. K., \& Govindarajan, V. (2000). Knowledge flows within multinational corporations. Strategic Management Journal, 21(4), 473-496.

Harzing, A. W. (1999). Managing the multinationals: An international study of control mechanisms. E. Elgar.

Harzing, A. W. (2001). An analysis of the functions of international transfer of managers in MNCs. Employee Relations, 23(6), 581-598.

Hinds, P. J., \& Mortensen, M. (2005). Understanding conflict in geographically distributed teams: The moderating effects of shared identity, shared context, and spontaneous communication. Organization Science, 16(3), 290307.

Holm, A. E., Decreton, B., Nell, P. C., \& Klopf, P. (2017). The Dynamic Response Process to Conflicting Institutional Demands in MNC Subsidiaries: An Inductive Study in the Sub-Saharan African E-Commerce Sector. Global Strategy Journal, 7(1), 104-124.

Hornsey, M. J., \& Hogg, M. A. (2000). Assimilation and diversity: An integrative model of subgroup relations. Personality and Social Psychology Review, 4(2), 143-156.

Howard, G. S. (1994). Why do people say nasty things about self-reports? Journal of Organizational Behavior, 15(5), 399-404.

Janssen, O. (2004). How fairness perceptions make innovative behavior more or less stressful. Journal of Organizational Behavior, 25(2), 201-215.

Kleinbaum, A. M., \& Stuart, T. E. (2014). Inside the black box of the corporate staff: Social networks and the implementation of corporate strategy. Strategic Management Journal, 35(1), 24-47.

Klueter, T., \& Monteiro, F. (2017). How does performance feedback affect boundary spanning in multinational corporations? Insights from technology scouts. Journal of Management Studies, 54(4), 483-510.

Kostova, T., Marano, V., \& Tallman, S. (2016). Headquarters-subsidiary relationships in MNCs: Fifty years of evolving research. Journal of World Business, 51(1), 176-184.

Kramer, R. M. (1999). Trust and distrust in organizations: Emerging perspectives, enduring questions. Annual Review of Psychology, 50(1), 569-598.

Lee, S. H., \& Williams, C. (2007). Dispersed entrepreneurship within multinational corporations: A community perspective. Journal of World Business, 42(4), 505-519.

Leksell, L., \& Lindgren, U. (1982). The board of directors in foreign subsidiaries. Journal of International Business Studies, 13(1), 27-38.

Lind, C. H., \& Kang, O. H. (2017). The Value-Adding Role of the Corporate Headquarters in Innovation Transfer Processes: The Issue of Headquarters Knowledge Situation. Management International Review, 57(4), 1-32.

Malhotra, N. K., Kim, S. S., \& Patil, A. (2006). Common method variance in IS research: A comparison of alternative approaches and a reanalysis of past research. Management Science, 52(12), 1865-1883.

Marvel, M. R., Griffin, A., Hebda, J., \& Vojak, B. (2007). Examining the technical corporate entrepreneurs' motivation: Voices from the field. Entrepreneurship Theory and Practice, 31(5), 753-768.

Morrison, E. W., \& Phelps, C. C. (1999). Taking charge at work: Extrarole efforts to initiate workplace change. Academy of Management Journal, 42(4), 403-419.

Mudambi, R. (2011). Hierarchy, coordination, and innovation in the multinational enterprise. Global Strategy Journal, 1(3-4), 317-323.

Nahapiet, J., \& Ghoshal, S. (1998). Social capital, intellectual capital, and the organizational advantage. Academy of Management Review, 23(2), 242-266. 
Narula, R. (2014). Exploring the paradox of competence-creating subsidiaries: balancing bandwidth and dispersion in MNEs. Long Range Planning, 47(1), 4-15.

Nell, P. C., \& Ambos, B. (2013). Parenting advantage in the MNC: An embeddedness perspective on the value added by headquarters. Strategic Management Journal, 34(9), 1086-1103.

Nell, P. C., Decreton, B., \& Ambos, B. (2016). How Does Geographic Distance Impact the Relevance of HQ Knowledge? The Mediating Role of Shared Context. In Perspectives on Headquarters-subsidiary Relationships in the Contemporary MNC (pp. 275-298). Emerald Group Publishing Limited.

Ng, T. W., Feldman, D. C. 2012. A comparison of self-ratings and non-self-report measures of employee creativity. Human Relations, 65(8), 1021-1047.

Nohria, N., \& Ghoshal, S. (1994). Differentiated fit and shared values: Alternatives for managing headquarterssubsidiary relations. Strategic Management Journal, 15(6), 491-502.

Noorderhaven, N., \& Harzing, A. W. (2009). Knowledge-sharing and social interaction within MNEs. Journal of International Business Studies, 40(5), 719-741.

Nuruzzaman, N., Gaur, A. S., \& Sambharya, R. B. (2017). A Microfoundations Approach to Studying Innovation in Multinational Subsidiaries. Global Strategy Journal.

O'Brien, D., Sharkey Scott, P., Andersson, U., Ambos, T., \& Fu, N. 2018. The Micro-Foundations of Subsidiary Initiatives: How Subsidiary-Manager Activities Unlock Entrepreneurship. Global Strategy Journal.

Pant, A., \& Ramachandran, J. Navigating identity duality in multinational subsidiaries: A paradox lens on identity claims at Hindustan Unilever 1959-2015. Journal of International Business Studies, 48(6), 1-29.

Perlmutter, H. V. (1969). The tortuous evolution of the multinational corporation. Columbia Journal of World Business, 4(1), 9-18.

Podsakoff, P. M., MacKenzie, S. B., Lee, J.-Y., Podsakoff, N. P. 2003. Common method biases in behavioral research: A critical review of the literature and recommended remedies. Journal of Applied Psychology, 88(5), 879-903.

Podsakoff, P. M., Organ, D. W. 1986. Self-Reports in Organizational Research: Problems and Prospects. Journal of Management, 12(4), 531-544.

Prahalad, C. K., \& Bettis, R. A. (1986). The dominant logic: A new linkage between diversity and performance. Strategic Management Journal, 7(6), 485-501.

Reade, C. (2001). Dual identification in multinational corporations: Local managers and their psychological attachment to the subsidiary versus the global organization. International Journal of Human Resource Management, 12(3), 405-424.

Reade, C. (2003). Going the extra mile: Local managers and global effort. Journal of Managerial Psychology, 18(3), 208-228.

Schmid, S., Dzedek, L. R., \& Lehrer, M. (2014). From rocking the boat to wagging the dog: A literature review of subsidiary initiative research and integrative framework. Journal of International Management, 20(2), 201218.

Schotter, A. P., Mudambi, R., Doz, Y. L., \& Gaur, A. (2017). Boundary spanning in global organizations. Journal of Management Studies, 54(4), 403-421.

Schotter, A., \& Beamish, P. W. (2011). Performance effects of MNC headquarters-subsidiary conflict and the role of boundary spanners: The case of headquarter initiative rejection. Journal of International Management, $17(3), 243-259$.

Schulz, M. (2003). Pathways of relevance: Exploring inflows of knowledge into subunits of multinational corporations. Organization Science, 14(4), 440-459.

Shalley, C. E., Zhou, J., \& Oldham, G. R. (2004). The effects of personal and contextual characteristics on creativity: where should we go from here?. Journal of Management, 30(6), 933-958.

Smale, A., Björkman, I., Ehrnrooth, M., John, S., Mäkelä, K., \& Sumelius, J. (2015). Dual values-based organizational identification in MNC subsidiaries: A multilevel study. Journal of International Business Studies, 46(7), 761-783. 
Stea, D., Foss, K., \& Foss, N. J. (2015). A neglected role for organizational design: supporting the credibility of delegation in organizations. Journal of Organization Design, 4(3), 3-17.

Strutzenberger, A., \& Ambos, T. C. (2014). Unravelling the subsidiary initiative process: A multilevel approach. International Journal of Management Reviews, 16(3), 314-339.

Taggart, J. H. (1997). Autonomy and procedural justice: a framework for evaluating subsidiary strategy. Journal of International Business Studies, 28(1), 51-76.

Tajfel, H., \& Turner, J. C. (1979). An integrative theory of intergroup conflict. The social psychology of intergroup relations, 33(47), 74.

Tippmann, E., Sharkey Scott, P., \& Parker, A. (2017). Boundary capabilities in MNCs: Knowledge transformation for creative solution development. Journal of Management Studies, 54(4), 455-482.

ul Haq, H., Drogendijk, R., \& Holm, D. B. (2017). Attention in words, not in deeds: Effects of attention dissonance on headquarters-subsidiary communication in multinational corporations. Journal of World Business, 52(1), 111-123.

Van Maanen, J., \& Schein, E. H. 1979. Towards a theory of organizational socialization. In B. M. Staw (Ed.), Research in Organizational Behavior, vol. 1: 209-264. Greenwich, Conn.: JAI Press

Vora, D., Kostova, T., \& Roth, K. (2007). Roles of subsidiary managers in multinational corporations: The effect of dual organizational identification. Management International Review, 47(4), 595-620.

Vora, D., \& Kostova, T. (2007). A model of dual organizational identification in the context of the multinational enterprise. Journal of Organizational Behavior, 28(3), 327-350.

Yamin, M., Tsai, H., Holm, U. (2011). The performance effects of headquarters' involvement in lateral innovation transfers in multinational corporations. Management International Review, 51(2), 157-177. 


\section{TABLES AND FIGURES}

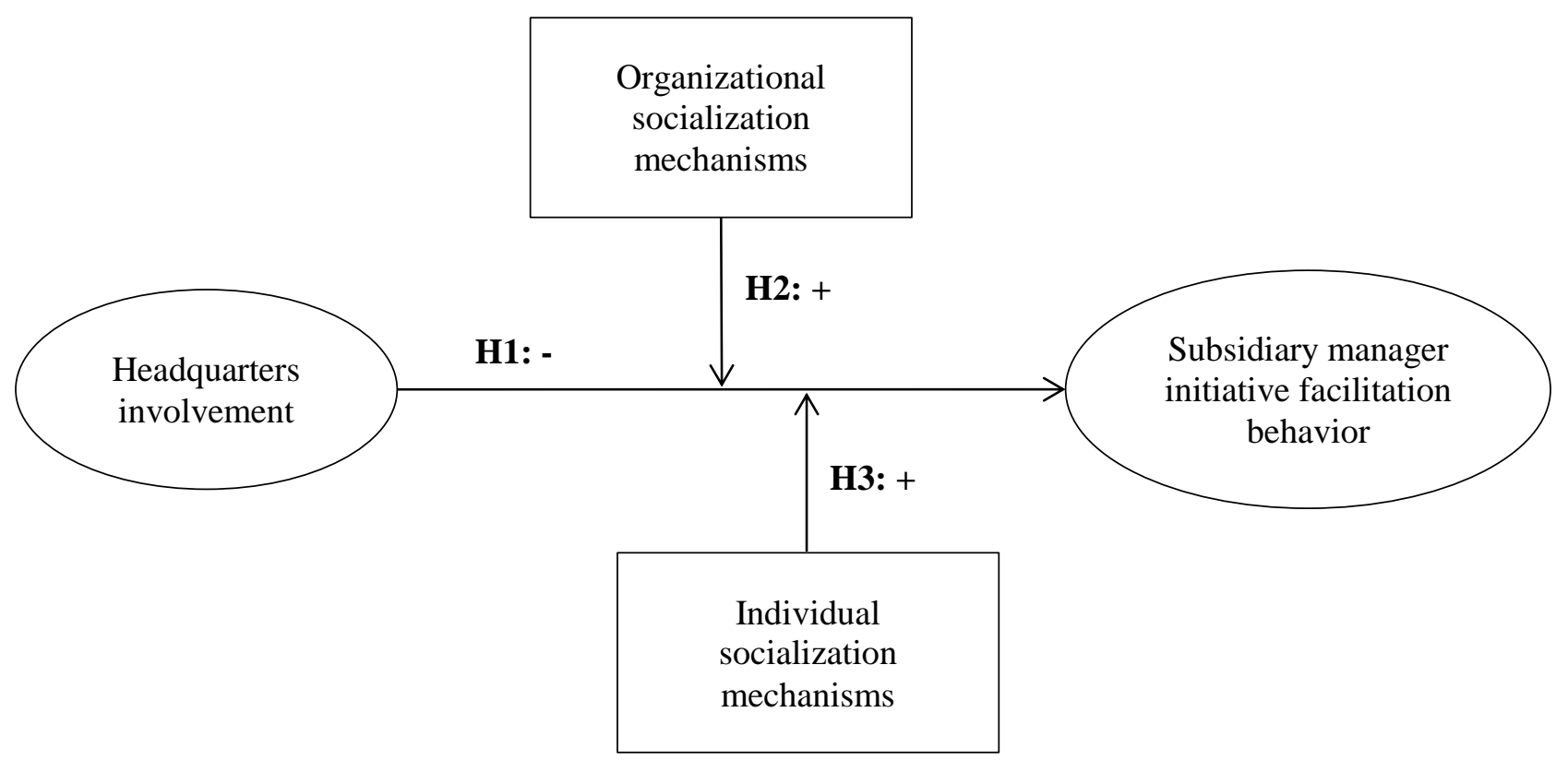

Figure 1 . The hypothesized model 
Table 1. Means, standard deviations and correlations

\begin{tabular}{|c|c|c|c|c|c|c|c|c|c|}
\hline & & 1 & 2 & 3 & 4 & 5 & 6 & 7 & 8 \\
\hline 1 & $\begin{array}{l}\text { Subsidiary manager initiative } \\
\text { facilitation behavior }\end{array}$ & 1.000 & & & & & & & \\
\hline 2 & Subsidiary manager age & 0.079 & 1.000 & & & & & & \\
\hline 3 & Subsidiary manager education & -0.011 & -0.010 & 1.000 & & & & & \\
\hline 4 & Subsidiary age & 0.019 & -0.032 & 0.024 & 1.000 & & & & \\
\hline 5 & Subsidiary size & 0.102 & 0.071 & -0.031 & 0.041 & 1.000 & & & \\
\hline 6 & Past subsidiary initiatives & $0.488 * * *$ & 0.075 & -0.040 & 0.105 & $0.171 *$ & 1.000 & & \\
\hline 7 & Geographic distance & -0.099 & 0.039 & -0.095 & -0.148 & 0.129 & 0.103 & 1.000 & \\
\hline 8 & $\begin{array}{l}\text { Main headquarters is corporate } \\
\text { headquarters }\end{array}$ & $-0.194 * *$ & 0.070 & 0.068 & -0.064 & 0.067 & -0.093 & 0.066 & 1.000 \\
\hline 9 & Entrepreneurial mandate & $0.228 * *$ & 0.029 & 0.106 & -0.049 & 0.149 & $0.252 * * *$ & -0.026 & $0.159 *$ \\
\hline 10 & Organizational socialization & 0.113 & 0.007 & 0.129 & 0.126 & $0.228 * *$ & $0.229 * *$ & -0.103 & -0.006 \\
\hline 11 & Individual socialization & $0.283 * * *$ & 0.079 & 0.136 & $-0.185^{* *}$ & 0.071 & 0.099 & -0.124 & -0.067 \\
\hline \multirow[t]{4}{*}{12} & Headquarters involvement & 0.018 & 0.009 & -0.039 & -0.083 & 0.101 & 0.005 & 0.051 & -0.063 \\
\hline & Mean & 5.875 & 50.45 & 0.792 & 28 & 234 & 4.918 & 1388 & 0.775 \\
\hline & S.D. & 0.836 & 7.515 & 0.408 & 24 & 327 & 1.332 & 2657 & 0.419 \\
\hline & & 9 & 10 & 11 & 12 & & & & \\
\hline 9 & Entrepreneurial mandate & 1.000 & & & & & & & \\
\hline 10 & Organizational socialization & $0.152 *$ & 1.000 & & & & & & \\
\hline 11 & Individual socialization & $0.152 *$ & 0.117 & 1.000 & & & & & \\
\hline \multirow[t]{3}{*}{12} & Headquarters involvement & 0.072 & $0.257 * * *$ & 0.045 & 1.000 & & & & \\
\hline & Mean & 0.658 & 4.944 & 0.683 & 2.829 & & & & \\
\hline & S.D. & 0.476 & 1.221 & 0.467 & 1.281 & & & & \\
\hline
\end{tabular}

$* * * \mathrm{p}<0.01, * * \mathrm{p}<0.05, * \mathrm{p}<0.1 ; \mathrm{N}=120$ 
Table 2. Results of OLS regressions models - dependent variable: subsidiary manager initiative facilitation behavior

\begin{tabular}{|c|c|c|c|c|c|c|}
\hline VARIABLES & Model 1 & Model 2 & Model 3 & Model 4 & Model 5 & Model 6 \\
\hline Subsidiary Manager Age (logged) & $\begin{array}{c}0.145 \\
(0.445)\end{array}$ & $\begin{array}{c}0.106 \\
(0.448)\end{array}$ & $\begin{array}{c}0.104 \\
(0.449)\end{array}$ & $\begin{array}{c}0.097 \\
(0.437)\end{array}$ & $\begin{array}{l}-0.036 \\
(0.463)\end{array}$ & $\begin{array}{l}-0.015 \\
(0.449)\end{array}$ \\
\hline Subsidiary Manager Education (dummy) & $\begin{array}{l}-0.013 \\
(0.187)\end{array}$ & $\begin{array}{l}-0.047 \\
(0.172)\end{array}$ & $\begin{array}{l}-0.053 \\
(0.173)\end{array}$ & $\begin{array}{l}-0.063 \\
(0.159)\end{array}$ & $\begin{array}{l}-0.029 \\
(0.175)\end{array}$ & $\begin{array}{l}-0.042 \\
(0.164)\end{array}$ \\
\hline Subsidiary Age (logged) & $\begin{array}{l}-0.037 \\
(0.098)\end{array}$ & $\begin{array}{c}0.030 \\
(0.096)\end{array}$ & $\begin{array}{c}0.024 \\
(0.098)\end{array}$ & $\begin{array}{l}-0.017 \\
(0.098)\end{array}$ & $\begin{array}{c}0.009 \\
(0.098)\end{array}$ & $\begin{array}{l}-0.023 \\
(0.097)\end{array}$ \\
\hline Subsidiary Size (logged) & $\begin{array}{c}0.065 \\
(0.072)\end{array}$ & $\begin{array}{c}0.058 \\
(0.069)\end{array}$ & $\begin{array}{c}0.058 \\
(0.069)\end{array}$ & $\begin{array}{c}0.031 \\
(0.073)\end{array}$ & $\begin{array}{c}0.040 \\
(0.073)\end{array}$ & $\begin{array}{c}0.020 \\
(0.075)\end{array}$ \\
\hline Subsidiary Past Initiatives (centered) & $\begin{array}{c}0.420 * * * \\
(0.087)\end{array}$ & $\begin{array}{c}0.417 * * * \\
(0.088)\end{array}$ & $\begin{array}{c}0.415 * * * \\
(0.087)\end{array}$ & $\begin{array}{c}0.447 * * * \\
(0.082)\end{array}$ & $\begin{array}{c}0.426 * * * \\
(0.081)\end{array}$ & $\begin{array}{c}0.451 * * * \\
(0.079)\end{array}$ \\
\hline Geographic Distance (logged) & $\begin{array}{c}-0.054 * * \\
(0.026)\end{array}$ & $\begin{array}{l}-0.036 \\
(0.029)\end{array}$ & $\begin{array}{l}-0.038 \\
(0.031)\end{array}$ & $\begin{array}{l}-0.042 \\
(0.030)\end{array}$ & $\begin{array}{l}-0.029 \\
(0.029)\end{array}$ & $\begin{array}{l}-0.033 \\
(0.029)\end{array}$ \\
\hline Main Headquarters is Corporate HQ (dummy) & $\begin{array}{c}-0.437 * * \\
(0.172)\end{array}$ & $\begin{array}{c}-0.386 * * \\
(0.170)\end{array}$ & $\begin{array}{c}-0.392 * * \\
(0.168)\end{array}$ & $\begin{array}{c}-0.434 * * * \\
(0.159)\end{array}$ & $\begin{array}{c}-0.440 * * \\
(0.173)\end{array}$ & $\begin{array}{c}-0.467 * * * \\
(0.164)\end{array}$ \\
\hline Entrepreneurial Mandate (dummy) & $\begin{array}{l}0.284 * \\
(0.169)\end{array}$ & $\begin{array}{c}0.242 \\
(0.168)\end{array}$ & $\begin{array}{c}0.245 \\
(0.170)\end{array}$ & $\begin{array}{l}0.280 * \\
(0.162)\end{array}$ & $\begin{array}{l}0.319^{*} \\
(0.165)\end{array}$ & $\begin{array}{c}0.334 * * \\
(0.162)\end{array}$ \\
\hline Organizational Socialization (centered) & & $\begin{array}{l}-0.052 \\
(0.094)\end{array}$ & $\begin{array}{l}-0.045 \\
(0.092)\end{array}$ & $\begin{array}{l}-0.023 \\
(0.087)\end{array}$ & $\begin{array}{l}-0.051 \\
(0.093)\end{array}$ & $\begin{array}{l}-0.031 \\
(0.086)\end{array}$ \\
\hline Individual Socialization (dummy) & & $\begin{array}{c}0.432 * * \\
(0.185)\end{array}$ & $\begin{array}{c}0.428 * * \\
(0.187)\end{array}$ & $\begin{array}{c}0.363 * * \\
(0.175)\end{array}$ & $\begin{array}{c}0.442 * * \\
(0.185)\end{array}$ & $\begin{array}{c}0.384 * * \\
(0.172)\end{array}$ \\
\hline H1: HQ Involvement (centered) & & & $\begin{array}{c}\mathbf{- 0 . 0 2 2} \\
(0.081)\end{array}$ & $\begin{array}{l}\mathbf{- 0 . 0 8 4} \\
(0.075)\end{array}$ & $\begin{array}{c}-\mathbf{- 0 . 3 7 1 * * *} \\
(0.170)\end{array}$ & $\begin{array}{c}-\mathbf{0 . 3 5 8 * * *} \\
(0.153)\end{array}$ \\
\hline H2: HQ Involvement * Organizational Socialization & & & & $\begin{array}{c}\mathbf{0 . 2 1 2} * * \\
(0.088)\end{array}$ & & $\begin{array}{c}\text { 0.181*** } \\
(0.088)\end{array}$ \\
\hline H3: HQ Involvement * Individual Socialization & & & & & $\begin{array}{c}\mathbf{0 . 4 3 9} * * \\
(0.187)\end{array}$ & $\begin{array}{c}\mathbf{0 . 3 5 6}^{* * *} \\
(0.172)\end{array}$ \\
\hline Constant & $\begin{array}{l}-0.307 \\
(1.774)\end{array}$ & $\begin{array}{l}-0.707 \\
(1.768)\end{array}$ & $\begin{array}{l}-0.656 \\
(1.799)\end{array}$ & $\begin{array}{l}-0.344 \\
(1.772)\end{array}$ & $\begin{array}{l}-0.078 \\
(1.855)\end{array}$ & $\begin{array}{c}0.078 \\
(1.817)\end{array}$ \\
\hline $\begin{array}{l}\text { Observations } \\
\text { R-squared }\end{array}$ & $\begin{array}{c}120 \\
0.300^{* * *}\end{array}$ & $\begin{array}{c}120 \\
0.336^{* * *}\end{array}$ & $\begin{array}{c}120 \\
0.336^{* * *}\end{array}$ & $\begin{array}{c}120 \\
0.370^{* * *}\end{array}$ & $\begin{array}{c}120 \\
0.364 * * *\end{array}$ & $\begin{array}{c}120 \\
0.387 * * *\end{array}$ \\
\hline
\end{tabular}

Robust standard errors in parentheses; ${ }^{* * *} \mathrm{p}<0.01,{ }^{* *} \mathrm{p}<0.05,{ }^{*} \mathrm{p}<0.1$ 


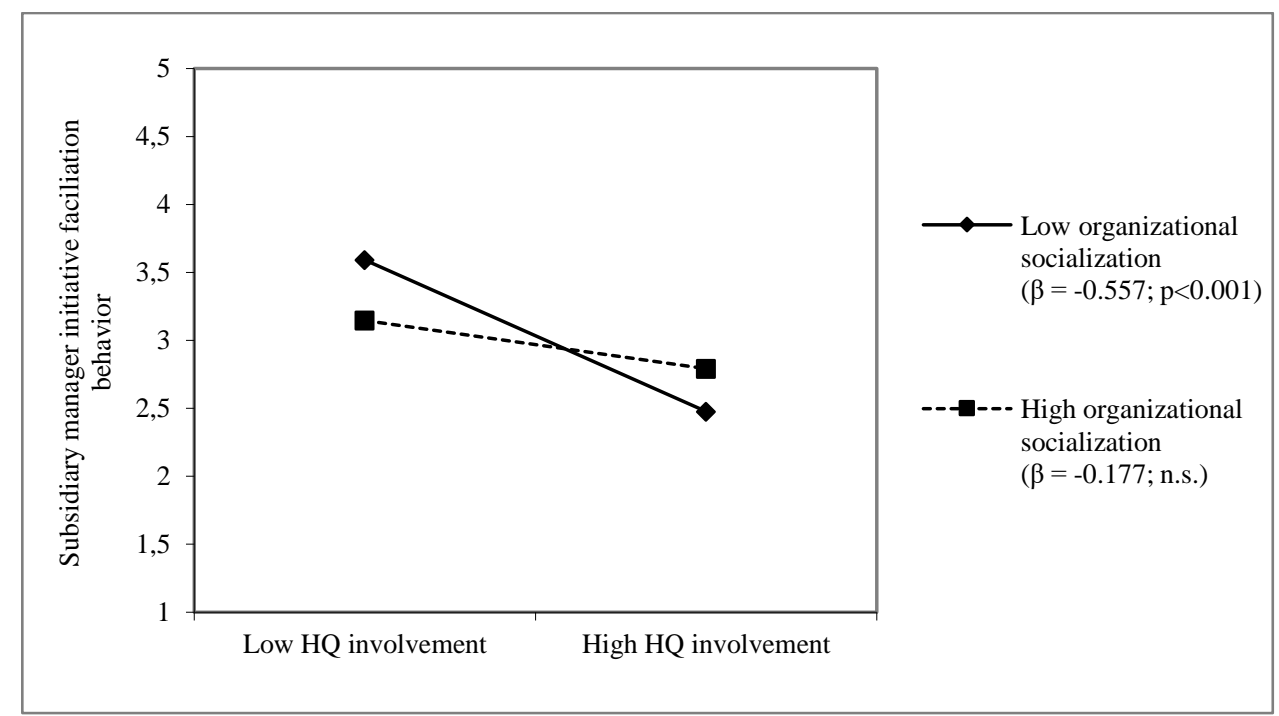

Figure 2. Moderating effect of organizational socialization on the relationship between headquarters involvement and subsidiary manager initiative facilitation behavior (constant set to 3 )

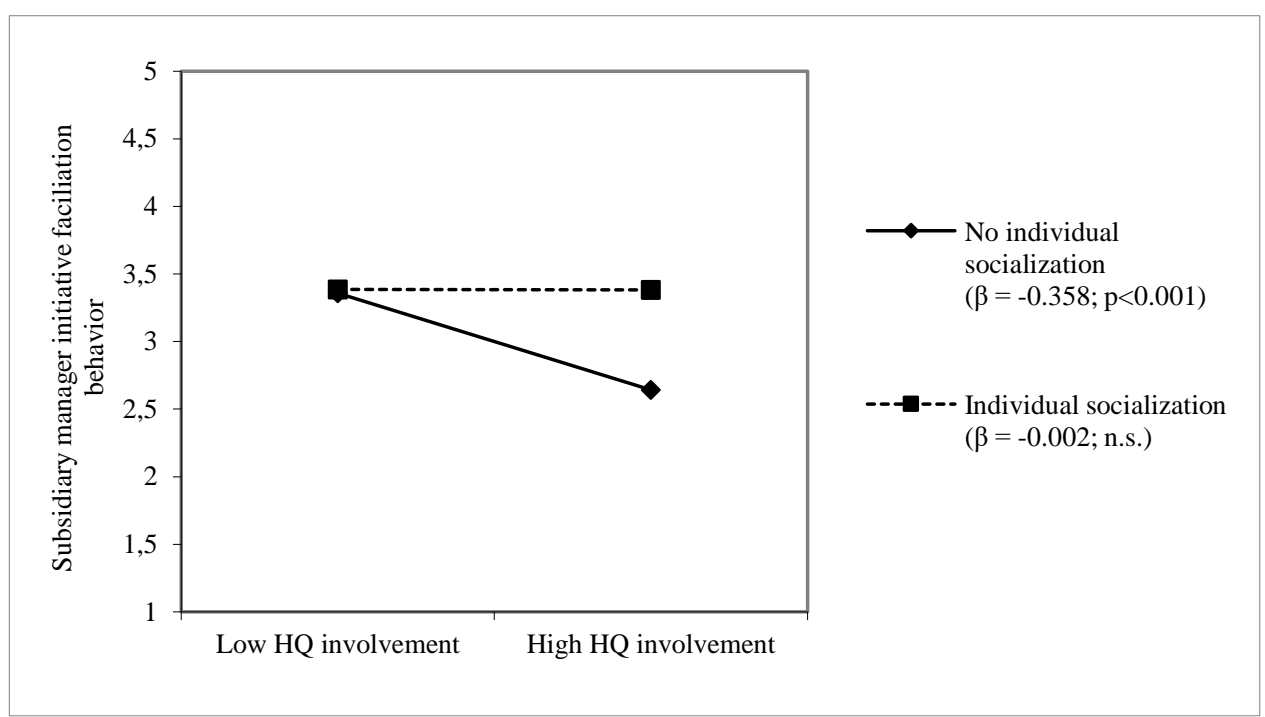

Figure 3. Moderating effect of individual socialization on the relationship between headquarters involvement and subsidiary manager initiative facilitation behavior (constant set to 3) 